\title{
Studi Komparatif Lukisan Perempuan Perupa dengan Pria Perupa Impresionis dalam Tema Kehidupan Keseharian
}

\author{
Ira Adriati Winarno ${ }^{1} \&$ Agus Sachari ${ }^{2}$ \\ ${ }^{1}$ KK Ilmu Seni dan Estetika-FSRD- ITB \\ ${ }^{2}$ KK Ilmu Desain dan Budaya Visual
}

\begin{abstract}
Impressionism is an art movement that firstly established in France in the middle of 19th century. Claude Monet, Ėdouard Manet, Pierre-Auguste Renoir, and Edgar Degas are famous male impressionist artists that were known by many, yet there are famous female impressionist artists such as Berthe Morisot, Mary Cassatt, Eva Gonzales, and Marie Bracquemond that deserve to be known as well.

The presented paper discusses the aesthetics value and meanings of paintings of these female impressionist artists, through the perspective of art criticism, historical method, and women studies. Object of analysis are paintings that depicting domestic life made by mentioned artists above.

Results show that the depicted domestic life in those paintings presented a unique gaze of a woman, as shown in the representation of body language to express the relationship between mother and children. Thus, female impressionist paintings emphasize more on the activities and aspiration of women than the beauty of their bodies. The painted theme shows that the artists express gender equality and/or independent (or self-supporting) women, which are presented in an equal aesthetic quality compared to those of male impressionist artists.
\end{abstract}

Keywords: domestic life; female gaze; impressionism; women artists.

\section{$1 \quad$ Pendahuluan}

Perempuan perupa bergaya Impresionisme yang dicatat dalam sejarah seni rupa Barat hanya Berthe Morisot dan Mary Cassatt. Padahal selain keduanya, masih terdapat perempuan perupa yang aktif berkarya dalam periode Impresionisme. Keberhasilan perempuan perupa dalam berkarya senantiasa dikaitkan dengan pria pelukis yang menjadi suami atau sahabat mereka.

Beberapa ahli sejarah seni yang membahas perempuan perupa Impresionisme antara lain Norma Broude dalam tulisan berjudul Mary Cassatt Modern Woman or the Cult of True Womanhood? Dalam tulisannya, Broude membahas karya mural Mary Cassatt yang dibuat untuk the Woman's Building, World's Colombian Exposition, Chicago 1893 [1]. Tulisan itu belum membahas tema 
karya perempuan perupa bergaya Impresionisme lainnya. Pembahasan mengenai perempuan perupa dalam periode Impresionisme dinilai penting, karena gaya Impresionisme merupakan salah satu yang mempengaruhi perkembangan munculnya seni rupa modern.

Untuk memahami kualitas karya perempuan perupa Impresionisme, tulisan ini memaparkan dan membahas karya-karya mereka dengan metode kritik seni dan historis. Kritik seni digunakan untuk mengetahui nilai estetis karya, sedangkan metode historis untuk memahami situasi sosial pada abad ke- 19 di Eropa. Hasil penelitian ini merupakan kajian gender (feministis), karena memfokuskan pada keberadaan perempuan dan menganalisis aspirasi (khususnya karya seni rupa) perempuan dari sudut pandang perempuan.

\section{Impresionisme}

Dalam pameran Impresionisme yang pertama tahun 1874 dipamerkan 165 karya para pelukis aliran tersebut seperti Monet, Degas, Renoir, Pissaro, Cezzanne, Sisley, Boundin, Guillaumin, termasuk Morisot. Pameran diselenggarakan setelah sikap kejam yang dilakukan oleh Salon pada tahun 1873 yang menyingkirkan karya-karya mereka. Kelompok ini pertama kali berpameran di studio seorang fotografer bernama Nadar sepanjang bulan April hingga Mei 1874. Selanjutnya pameran-pameran Impresionisme berlangsung di antara tahun $1876-1886$ [2].

Sebutan Impresionisme berasal dari judul Impression: Sunrise (1872) (Impresi: Fajar Menyingsing) pada salah satu lukisan Monet menyebabkan para pengkritik menyebut mereka "impresionis". Claude Monet lebih menyukai istilah "kesesaatan", karena perhatian pokoknya ada pada apa yang terjadi sesaat dan serentak, yaitu pengaruh yang berubah-ubah dari cahaya dan tercerapnya oleh mata pada suatu saat. Monet dan teman-teman sejawatnya mencapai ini dengan sapuan kuas singkat yang memecahkan warna sehingga menjadi warna-warni yang melimpah. Kelompok Impresionisme dalam karyanya, membuang perspektif dan detail. Gaya melukis tersebut bertentangan dengan selera masyarakat maupun akademi seni pada saat itu yang masih mengagungkan lukisan potret, keindahan alam maupun sosok telanjang dengan gaya klasik maupun gaya Renaisans.

Tabel di bawah ini memaparkan kecenderungan pilihan objek karya dari beberapa perupa Impresionisme [3]. 
Tabel 1 Perupa Impresionisme. (sumber: Winarno, I., Mencari Perempuan Perupa Dunia, Petik, Bandung, 2007)

\begin{tabular}{|c|c|c|c|}
\hline No. & Nama & $\begin{array}{c}\text { Kecenderungan Objek } \\
\text { Karya }\end{array}$ & Keterangan \\
\hline 1. & $\begin{array}{l}\text { Eugene } \\
\text { Boudin } \\
(1824-98)\end{array}$ & Landscape & $\begin{array}{l}\text { Salah satu pelukis yang } \\
\text { memelopori melukis di luar } \\
\text { ruangan. Claude Monet } \\
\text { dipengaruhi oleh Boudin. }\end{array}$ \\
\hline 2. & $\begin{array}{l}\text { Edouard } \\
\text { Manet } \\
(1832-83)\end{array}$ & $\begin{array}{l}\text { Aktifitas di bar atau kafe, } \\
\text { situasi di pantai, } \\
\text { perempuan, bunga, } \\
\text { studio, foto potrait } \\
\text { teman-temannya. }\end{array}$ & $\begin{array}{l}\text { Karya berjudul The Lunch on the } \\
\text { Grass } 1862-63 \text { dan Olympia } \\
\text { (1863) mengejutkan masyarakat } \\
\text { karena perubahan teknik maupun } \\
\text { kandungan makna karya. }\end{array}$ \\
\hline 3. & $\begin{array}{l}\text { Frederic } \\
\text { Bazille } \\
(1841-70)\end{array}$ & $\begin{array}{l}\text { Situasi keluarga maupun } \\
\text { situasi studio seniman } \\
\text { (kumpulan manusia yang } \\
\text { beraktifitas keseharian) }\end{array}$ & $\begin{array}{l}\text { Sebenarnya pelukis ini adalah } \\
\text { seorang mahasiswa kedokteran } \\
\text { yang menjadi teman Monet. }\end{array}$ \\
\hline 4. & $\begin{array}{l}\text { Claude Monet } \\
(1840-1926)\end{array}$ & $\begin{array}{l}\text { Landscape (kebun, } \\
\text { taman, pemandangan } \\
\text { alam), figure manusia }\end{array}$ & $\begin{array}{l}\text { Nama kelompok ini berasal dari } \\
\text { karyanya yang berjudul } \\
\text { Impression, Sunrise (1873). } \\
\text { Monet seorang pelukis yang paling } \\
\text { bersungguh-sungguh dlm } \\
\text { memperhatikan ketidaktetapan dari } \\
\text { cahaya yang diterima oleh suatu } \\
\text { objek. Termasuk ketika mengamati } \\
\text { perubahan warna muka jenazah } \\
\text { istrinya. }\end{array}$ \\
\hline 5. & $\begin{array}{l}\text { Alfred Sisley } \\
(1839-99)\end{array}$ & $\begin{array}{l}\text { Pemandangan } \\
\text { (Landscape) khususnya } \\
\text { sungai }\end{array}$ & $\begin{array}{l}\text { Pelukis ini hanya sedikit } \\
\text { menggambarkan aktifitas manusia. }\end{array}$ \\
\hline 6. & $\begin{array}{l}\text { Camille } \\
\text { Pissarro } \\
(1830-1903)\end{array}$ & $\begin{array}{l}\text { Pemandangan alam } \\
\text { khususnya desa-desa di } \\
\text { sekitar Paris. } \\
\text { Pissaro tertarik } \\
\text { memvisualisasikan } \\
\text { aktifitas perempuan di } \\
\text { rumah. }\end{array}$ & $\begin{array}{l}\text { Lukisannya memperlihatkan } \\
\text { suasana tenang. } \\
\text { Lukisannya dengan tema } \\
\text { perempuan dipamerkan pada } \\
\text { pameran Impresionis ke tujuh } \\
\text { tahun } 1882 \text {. }\end{array}$ \\
\hline 7. & $\begin{array}{l}\text { Pierre- } \\
\text { Auguste } \\
\text { Renoir } \\
(1841-1919)\end{array}$ & $\begin{array}{l}\text { Figur perempuan dan } \\
\text { pria dalam aktifitas } \\
\text { keseharian dan } \\
\text { pemandangan alam. }\end{array}$ & $\begin{array}{l}\text { Pelukis ini berasal dari keluarga } \\
\text { miskin yang kemudian } \\
\text { melanjutkan ke Academie des } \\
\text { Beaux-Arts } 1862 \text {. Kemudian } \\
\text { bertemu Sisley, Monet, dan Bazille } \\
\text { di studio Gleyre tahun } 1862 \text {. }\end{array}$ \\
\hline 8. & $\begin{array}{l}\text { Armand } \\
\text { Guillaumin } \\
(1841-1927)\end{array}$ & $\begin{array}{l}\text { Pemandangan alam } \\
\text { khususnya pemandangan } \\
\text { di dermaga }\end{array}$ & Dipengaruhi oleh Pissarro. \\
\hline
\end{tabular}




\begin{tabular}{|c|c|c|c|}
\hline No. & Nama & $\begin{array}{c}\text { Kecenderungan Objek } \\
\text { Karya }\end{array}$ & Keterangan \\
\hline 9. & $\begin{array}{l}\text { Edgar Degas } \\
(1834-1917)\end{array}$ & $\begin{array}{l}\text { Aktifitas manusia, seperti } \\
\text { suasana kafe, pacuan } \\
\text { kuda, pertunjukan balet }\end{array}$ & $\begin{array}{l}\text { Pertunjukan balet/ aktifitas balet } \\
\text { paling banyak dan menjadi ciri } \\
\text { khasnya. Ia juga membuat patung } \\
\text { penari balet. }\end{array}$ \\
\hline 10. & $\begin{array}{l}\text { Gustave } \\
\text { Caillebotte } \\
(1848-94)\end{array}$ & $\begin{array}{l}\text { Aktifitas manusia, seperti } \\
\text { suasana di kota. }\end{array}$ & $\begin{array}{l}\text { Seorang insinyur kelautan dan } \\
\text { pelukis amatir yang bertemu } \\
\text { dengan Degas, Renoir dalam } \\
\text { pameran } 1874 \text {. }\end{array}$ \\
\hline 11. & $\begin{array}{l}\text { Berthe } \\
\text { Morisot } \\
(1841-95)\end{array}$ & $\begin{array}{l}\text { Aktifitas perempuan dari } \\
\text { kalangan borjuis, } \\
\text { beberapa lukisan } \\
\text { pemandangan alam. }\end{array}$ & $\begin{array}{l}\text { Umumnya model yang dipilihnya } \\
\text { adalah anggota keluarga maupun } \\
\text { teman-temannya. }\end{array}$ \\
\hline 12. & $\begin{array}{l}\text { Mary Cassatt } \\
(1844-1926)\end{array}$ & $\begin{array}{l}\text { Aktifitas perempuan dan } \\
\text { anak-anak dari kalangan } \\
\text { borjuis. Pelukis ini juga } \\
\text { tertarik melukiskan } \\
\text { aktifitas di teater sebagai } \\
\text { akibat pengaruh dari } \\
\text { Degas. }\end{array}$ & $\begin{array}{l}\text { Perempuan Amerika yang } \\
\text { mengembangkan karier di Eropa } \\
\text { (Paris). }\end{array}$ \\
\hline 13. & $\begin{array}{l}\text { Paul Cezanne } \\
(1839-1906)\end{array}$ & $\begin{array}{l}\text { Pemandangan alam, } \\
\text { benda-benda (still life), } \\
\text { figur manusia }\end{array}$ & $\begin{array}{l}\text { Pelukis ini sangat menyenangi } \\
\text { melukis di luar ruangan, } \\
\text { meninggal sesuai keinginannya } \\
\text { pada saat melukis dalam badai } \\
\text { (selama ini ia terserang pneumonia } \\
\text { (sakit paru-paru). }\end{array}$ \\
\hline 14. & $\begin{array}{l}\text { George Seurat } \\
(1859-91)\end{array}$ & $\begin{array}{l}\text { Aktifitas manusia, di } \\
\text { alam maupun di sirkus. }\end{array}$ & $\begin{array}{l}\text { Pelukis ini sebenarnya bukan } \\
\text { seorang impresionis, tetapi ia } \\
\text { mendapat dukungan dari Pissaro. } \\
\text { Ia belajar impresionis tetapi } \\
\text { kemudian mengembangkan } \\
\text { gayanya sendiri. }\end{array}$ \\
\hline
\end{tabular}

Perupa Impresionisme seluruhnya melukiskan kehidupan keseharian manusia. Beberapa perupa cenderung melukiskan kehidupan malam di kafe-kafe, pemandangan alam, maupun pertunjukan opera. Perupa lain melukiskan keseharian perempuan dalam beberapa aktifitas seperti mandi, menyusui, mengasuh anak, dan lain-lain. Demikian pula dengan perempuan perupa yang masuk dalam kelompok tersebut, Berthe Morisot dan Mary Cassatt, melukiskan kehidupan keseharian.

Setelah kelompok Impresionisme terpecah, Impresionisme mulai mendapat tempat istimewa dan memberi pengaruh terhadap karya seni lukis di Prancis dan negara lainnya. Pengaruh tersebut terus berlangsung hingga abad ke-20. 
Impresionisme mempengaruhi seni rupa modern dalam hal menjadikan permukaan dua dimensi dalam objek-objek pada sebuah lukisan, penggunakan warna yang murni dan terang [2].

\section{$3 \quad$ Eksistensi Perempuan Perupa Impresionisme}

Perempuan perupa yang masuk dalam kelompok Impresionisme berdasarkan tulisan Whitney Chadwick dalam Women, Art, and Society, adalah Berthe Morisot, Marry Cassatt, Susan Mac Dowell Eakins, Eva Gonzales, dan Marie Bracquemond [4]. Dalam periode tahun 1870-an, dikenal pula pelukis Alice Barber Stephens dan Jenny Brownscombe yang memperoleh pendidikan di Art Student's League of New York.

Berthe Morisot merupakan perempuan perupa yang pertama kali bergabung dengan Impresionisme dan telah mengikuti pameran dengan tokoh-tokoh kelompok tersebut sejak tahun 1865, berpameran bersama Degas, Manet, Pissarro, Renoir, dan Monet. Setelah tahun 1879, Mary Cassatt yang berasal dari Amerika mulai bergabung dengan kelompok Impresionisme.

Perempuan perupa pada abad ke-19 dihadapkan pada pilihan untuk terus melanjutkan karier mereka sebagai perupa atau memutuskan untuk menikah. Seandainya mereka menikah, maka kemungkinan besar sulit bagi seorang perempuan untuk terus berprofesi sebagai perempuan perupa.

Beberapa perempuan perupa menikah dengan pria perupa, seperti Berthe Morisot yang menikah dengan saudara laki-laki Edouart Manet, Eugéne Manet tahun 1874. Berthe sangat beruntung karena suaminya memberikan keleluasan bagi dirinya untuk terus berkarya. Marie Bracquemond yang menikah dengan perupa Félix Bracquemond pada tahun 1869, pada awalnya Felix mendukung kegiatan artistik istrinya, namun selanjutnya Félix Bracquemond merasa iri dengan kemajuan artistik istrinya. Perempuan perupa lainnya yaitu saudara kandung Berthe Morisot bernama Edma, yang memiliki bakat seni sehebat Berthe Morisot, akhirnya tidak dapat menjadi perupa profesional setelah menikah dengan seorang anggota militer pada tahun 1869. Padahal pada tahun 1864, Berthe dan Edma Morisot meraih sukses dalam pameran bersama mereka.

Berbeda dengan Berthe Morisot maupun Marie Bracquemond, Mary Cassatt memutuskan untuk tidak menikah. Cassatt berusaha mempertahankan kebebasannya untuk tidak terikat dalam struktur patriarki yang ada dalam kehidupan berkeluarga.

Selain faktor pernikahan, faktor ekonomi keluarga maupun status sosial keluarga seorang perempuan perupa pada abad ke-19 sangat berpengaruh 
terhadap eksistensi mereka dalam medan sosial seni rupa. Berthe Morisot adalah seorang putri pejabat pada era tersebut. Kondisi finansial yang baik, memungkin Berthe dan Edma Morisot memperoleh pendidikan khusus melukis dari guru pribadi seperti Joseph Guichard, Corot, dan Oudinot. Mary Cassatt yang berasal dari Amerika adalah putri seorang pengusaha dari Pennsylvania. Casssatt menjadi siswa Pennsylvania Academy pada tahun 1861. Pada tahun 1866 Cassatt tinggal di Paris untuk mengembangkan karier sebagai perupa.

Kemapanan finansial membuat sebuah keluarga tidak membedakan perempuan maupun pria dalam memperoleh kesempatan meningkatkan pendidikan. Kemapanan finansial tersebut yang mendukung Berthe Morisot dan Mary Cassatt untuk dapat terus berkarya. Hal tersebut berpengaruh pula dalam sebuah keluarga baru, hal ini dialami oleh Berthe Morisot yang dapat tetap berkarya karena kondisi finansial yang baik.

Bila mencermati sebuah lukisan karya Alice Barber Stephens berjudul The Female Life Class (1879), terlihat cukup banyak perempuan yang berminat dan memiliki keahlian melukis pada tahun tersebut. Hanya saja, yang dapat eksis hingga terus tercatat dalam sejarah seni rupa dunia jumlahnya sangat sedikit. Kemungkinan faktor kelas sosial yang erat kaitannya dengan kemampuan finansial menjadi salah satu faktor penyebab amat sedikit perempuan perupa profesional era tersebut.

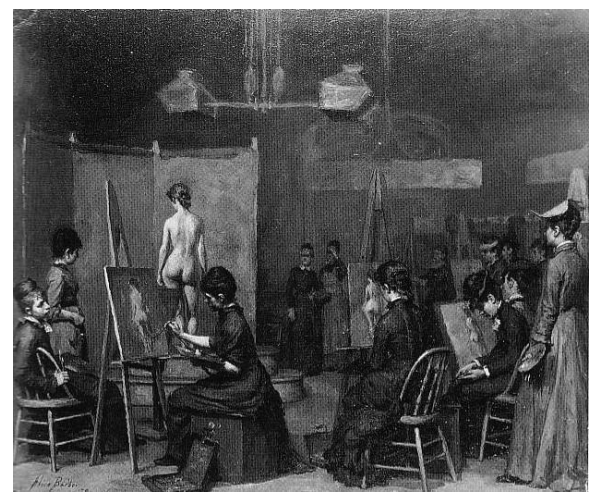

Gambar 1 Barber Stephens, The Female Life Class (1879). (Sumber: Chadwick, W., Women, Art, and Society, Fourth Edition, Thames and Hudson Ltd, London, 2007, hal. 231)

Faktor lain yang berpengaruh terhadap eksistensi seorang perempuan perupa adalah motivasi untuk terus belajar dan kepercayaan diri dalam menentukan gaya seni. Hal ini tampak dalam diri Mary Cassatt yang berani mengikuti gaya impresionismu karena menurut pendapatnya merupakan aliran modern pada saat itu. Cassatt juga tidak terpengaruh oleh penolakan-penolakan yang dilakukan 
oleh galeri terhadap karyanya yang disebutnya : "At last I could work with complete independence without concerning myself with the eventual judgment of a jury". Ia juga menyebutkan "I already knew who were my true masters. I admired Manet, Courbet, and Degas. I hated conventional art. I began to live." [4]

Motivasi dalam mengembangkan teknik baru selain teknik lukis yang selama ini telah ditekuni, dilakukan oleh Mary Cassatt dengan memasukkan kebudayaan Jepang ke kebudayaan Eropa (Japonisme). Beberapa karyanya kemudian memanfaatkan teknik mencetak dengan visualisasi yang datar seperti karya cetak Jepang pada saat itu. Salah satu karyanya berjudul The Coiffure 1891, color print with dry point, soft ground and aquatint, berukuran $36.5 \times 26.7 \mathrm{~cm}$, adalah salah satu karya Casssatt yang terpengaruh Japonisme.

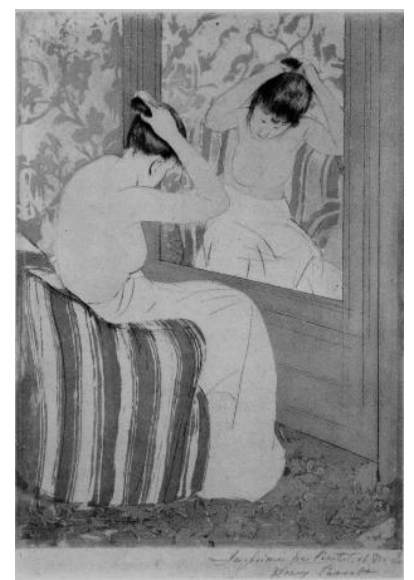

Gambar 2 Mary Cassatt, The Coiffure 1891, color print with dry point, soft ground and aquatint, berukuran 36.5 x $26.7 \mathrm{~cm}$. (Sumber: Honour, H. dan Fleming, J., A World History of Art, Forth Edition, Laurence King, London, 1995, h. 669.)

Selain faktor kelas sosial, kepercayaan diri, dan motivasi untuk maju, terdapat faktor penghambat eksistensi perempuan perupa pada saat itu, yaitu kecenderungan merendahkan kemampuan estetis perempuan perupa dari pria perupa. Pria perupa seringkali masih menyangsikan kemampuan estetis perempuan perupa. Salah satunya komentar dari pelukis Renoir, bahwa baginya perempuan perupa adalah menggelikan, tetapi secara pribadi menyenangi perempuan yang berprofesi sebagai penyanyi dan penari untuk dijadikan objek lukisan.

Berthe Morisot pernah mengalami sikap direndahkan oleh pria perupa. Morisot akhirnya mengambil jarak pertemanan dengan Manet, setelah pria tersebut 
menggoreskan kuas pada lukisan yang sedang dikerjakannya. Pemaparan tersebut memperlihatkan bahwa sebagai perempuan perupa, perempuan harus bekerja lebih keras hingga memperoleh pengakuan. Setelah mereka eksis pun, masyarakat maupun pria perupa seringkali menyangkutkan keberhasilan perempuan perupa dengan pria di sekelilingnya seperti sahabat, saudara lakilaki, ayah, atau suami.

Di sisi lain, kritikus pada saat itu mengakui kemampuan perempuan perupa impresionis. Norma Broude mengungkapkan dalam tulisannya,"Thus it was that the work of Berthe Morisot, who along with Cassatt and Marie Bracquemond exhibited on a fairly regular basis with the impressionist, could be consistently praised by critics for the same qualities that they objected to in the work of her male colleagues."[1]

\section{Tema Kehidupan Keseharian dalam Karya Perempuan Perupa Impresionis}

Perempuan perupa bergaya Impresionisme memilih tema yang berkaitan dengan kehidupan keseharian, serupa dengan pria perupa dalam era tersebut. Hal itu terjadi karena kaum impresionis mengembalikan seni untuk merekam kehidupan keseharian kehidupan manusia.

Perbedaan objek yang terjadi antara perempuan perupa dan pria perupa dalam pemilihan kehidupan keseharian terjadi karena perempuan tidak memiliki akses untuk menikmati kehidupan malam di kafe-kafe seperti yang dilakukan oleh kaum pria pada saat itu. Oleh karenanya tidak mengherankan bila kehidupan keseharian yang divisualiasikan oleh perempuan perupa sangat erat kaitannya dengan kehidupan domestik mereka. Kehidupan domestik adalah kegiatan keseharian perempuan yang berbasis tugas dalam rumah tangga. Selain itu, kegiatan luar rumah yang dilakukan oleh perempuan pada saat itu khususnya untuk kelas sosial atas adalah menonton opera maupun mengadakan piknik bersama keluarga.

Tema yang dipilih adalah aktifitas minum teh, berdandan, mengasuh anak, menonton opera, bermain di halaman, atau membaca. Selain tema-tema tersebut, Berthe Morisot perempuan perupa yang pertamakali bergabung dengan kaum impresionis, memvisualisasikan hubungan ayah dan anak dalam karya berjudul Eugene Manet and his Daughter in the Garden at Bougival (1881). Dalam karya tersebut digambarkan suami dan anaknya sedang berkumpul di sebuah taman. Makna yang ingin diungkapkan dari karyanya adalah memperlihatkan kehangatan hubungan ayah dan anak perempuan. Bagaimana seorang ayah meluangkan waktu dan memperhatikan secara seksama permainan 
anaknya. Visualisasi ini dianggap tidak umum bagi masyarakat patriartik, karena yang digambarkan bukan ibu dengan anaknya.

Di sisi lain, pemilihan tema oleh Berthe Morisot dalam lukisan Eugene Manet and his Daughter in the Garden at Bougival (1881) memperlihatkan kebebasan diri untuk mengungkapkan beragam tema dalam kehidupan keseharian. Keunikan tema ini memperlihatkan kreatifitas Berthe Morisot untuk membuat karya keseharian yang berbeda atau tidak umum. Dari segi teknik visualisasi, Berthe Morisot memilih sudut pandang dari sebelah pinggir untuk sosok ayah, dikomposisikan dengan anak perempuan yang diambil secara frontal.

Suasana di luar rumah, cukup sering dilukiskan oleh Berthe Morisot, antara lain lukisan di tepi pantai dan pelabuhan, seperti dalam karya berjudul Boats on the Seine (1871-72), lukisan galangan kapal dalam karya berjudul Boats under Construction (1874), In the Cornfield at Genneviliers (1875) menggambarkan ladang. Karya lukisan yang memperlihatkan aktifitas perempuan dan anaknya di alam terbuka terlihat dalam karya berjudul In a Park (On the Grass) (1874), tampak perempuan duduk bercengkrama dengan binatang peliharaannya, sedangkan anak perempuan berdiri lebih di belakang. Berthe Morisot melukiskan alam sekaligus kehidupan perempuan dan anaknya. Komposisi yang baik antara tumbuhan dan manusia dalam lukisan tersebut membuat suasana terasa sangat alamiah. Menempatkan anak perempuan pada bagian belakang memberikan kesan ruang yang luas dalam lukisan tersebut.

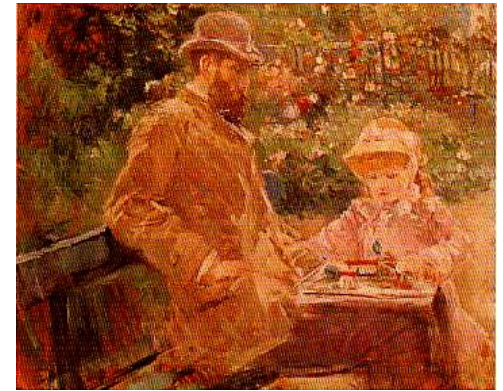

Gambar 3 Berthe Morisot, Eugéne Manet and his Daughter in the Garden at Bougival (1881). Sumber: Cunningham, A., Impressionist, Parragon Book, United Kingdom, 2002, h. 207.

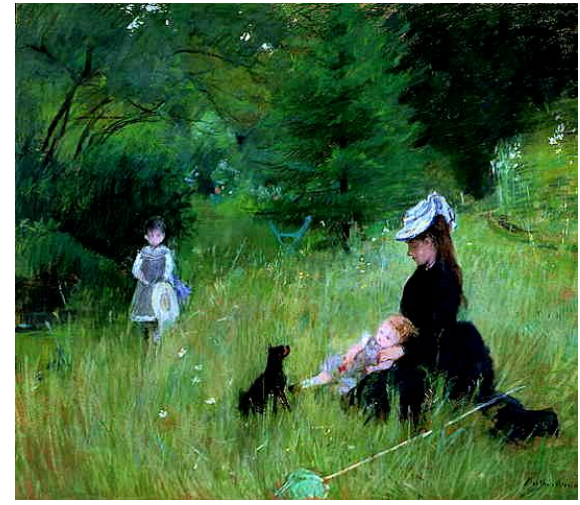

Gambar 4 Berthe Morisot, In a Park (On the Grass) (1874). Sumber: Web museum Paris, 2007.

Melalui karya Berthe Morisot, terlihat bahwa perempuan perupa impresionis mampu mengembangkan kreatifitas mereka dengan menghadirkan tema kehidupan kesehariannya. Pengambilan tema yang tidak umum dan 
memvisualisasikan dengan sudut pandang yang menarik, telah memberikan nilai estetis yang baik dalam karya mereka.

Hal yang menarik adalah membandingkan cara pandang perempuan perupa dengan pria perupa dalam memvisualisasikan tema kehidupan sehari-hari, yaitu: "Apakah terdapat kesamaan ataukah perempuan perupa memperlihatkan kekhasan cara pandang mereka dalam mengangkat tema kehidupan keseharian?". Melalui karya Mary Cassatt dan Pierre-Auguste Renoir, dapat dicermati perbedaan visualisasi perempuan perupa dan pria perupa. Sebagai contoh dapat dicermati karya Mary Cassatt berjudul Young Mother Nursing Her Child (1898) yang memvisualisasikan seorang ibu muda menyusui anaknya, bila dibandingkan dengan karya Pierre-Auguste Renoir berjudul Maternity; Woman Feeding Her Baby (1886), tampak nyata sudut pandang pria dan perempuan perupa yang berbeda.

Renoir tidak mampu memperlihatkan bagaimana ekspresi kasih sayang dan perasaan ibu ketika menyusui melalui bahasa tubuh objek yang dilukisnya. Ibu dalam lukisan Renoir terlihat tidak mempedulikan anaknya dan lebih fokus kepada pelukis. Hal ini tentu saja karena pelukisnya merasa lebih memerlukan wajah cantik ibu yang menyusui daripada penggambaran perasaan seorang ibu ketika menyusui. Mary Cassatt tidak memperlihatkan seluruh wajah ibu yang menyusui, tetapi pengamat dapat merasakan kasih sayang ibu melalui interaksi pandangan mata antara ibu dan anaknya. Pose yang dipilih oleh Cassatt lebih banyak berbicara tentang kasih sayang seorang ibu yang sedang menyusui daripada yang dilukiskan oleh Renoir.

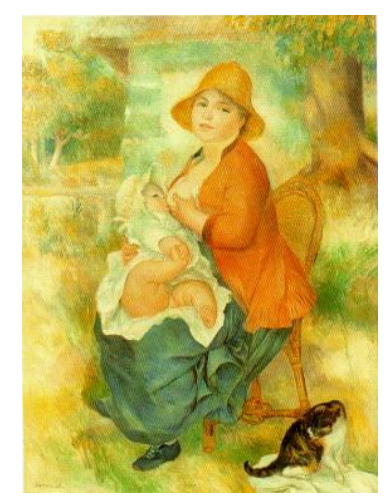

Gambar 5 Pierre-Auguste Renoir, Maternity; Woman Feeding Her Baby (1886). Sumber: Cunningham, A., Impressionist, Parragon Book, United Kingdom, 2002, h. 145.

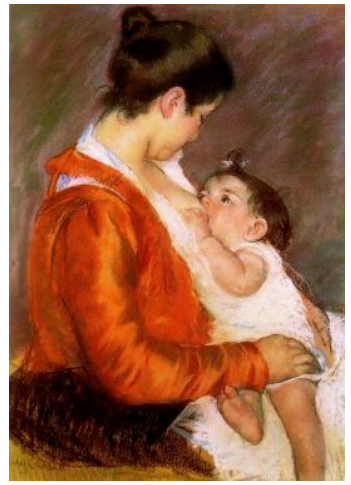

Gambar 6 Mary Cassatt berjudul Young Mother Nursing Her Child (1898). Sumber: Brodskaïa, N., Cassatt, Grange Book, London, 2006, h. 203. 
Karya lain yang menarik untuk dibandingkan adalah karya Mary Cassatt The Boating Party, (1893-94) dan Edouard Manet Boating, (1874). Lois Fishner dalam bukunya Understanding Art, mengajak pembaca untuk mencoba membandingkan kedua karya tersebut. Karya Mary Cassatt yang dibuat dua puluh tahun setelah karya Edouard Manet, kemungkinan besar memperoleh ide dari lukisan Manet. Selanjutnya Fishner mengajak pembaca untuk mencermati perbedaan keduanya [5].

Terlihat jelas perbedaan dalam meletakkan posisi perempuan dan pria sebagai objek utama dalam karya. Edouard Manet memfokuskan pria sebagai objek utama dan perempuan sebagai pelengkap, sedangkan Mary Cassatt justru menempatkan perempuan yang sedang menggendong anaknya sebagai fokus utama. Perbedaan tersebut mempertegas cara pandang yang berbeda antara perempuan dan pria perupa dalam menampilkan objek lukisannya. Mary Cassatt memfokuskan pada sosok perempuan sebagai sosok utama, dikarenakan ia ingin mengungkapkan betapa pentingnya tugas domestik yang selama ini diemban oleh seorang perempuan.

Di sisi lain Edouard Manet memperlihatkan sikap pria yang menegaskan sebagai sosok penguasa atau tokoh sentral dalam kehidupan. Dengan demikian terlihat perbedaan cara pandang antara perempuan dan pria perupa impresionis melalui penempatan objek lukisan maupun dalam mengekspresikan tokoh dalam lukisan. Dari segi teknik tidak tampak perbedaan kemampuan penguasaan teknik antara Mary Cassatt dengan Edouard Manet. Seandainya belum mengetahui karya berjudul The Boating Party, (1893-94) dilukis oleh perempuan, tentu pengamat tidak dapat melihat perbedaan penguasaan teknik antara perempuan dan pria perupa dalam teknik melukis.

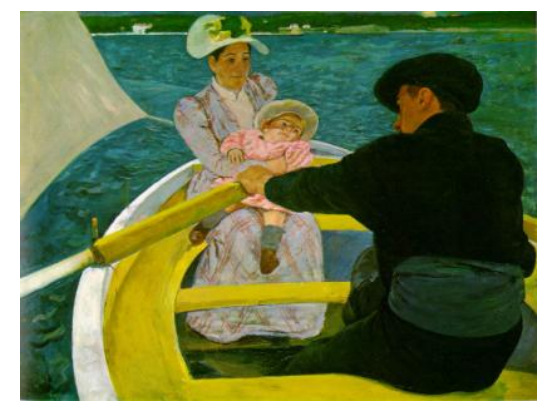

Gambar 7 Mary Cassatt, The Boating Party, (1893-94). Sumber: Fichner, L., Understanding Art, Forth ed., Prentice Hall, New Jersey, 1995. h. 406.

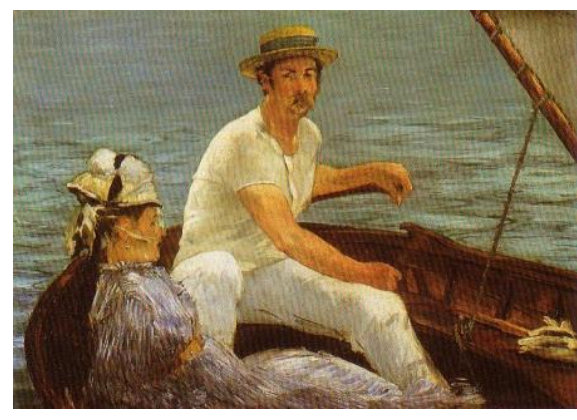

Gambar 8 Edouard Manet, Boating, (1874). Sumber: Fichner, L., Understanding Art, Forth ed., Prentice Hall, New Jersey, 1995. h. 406. 
Perempuan perupa impresionis dapat berbicara tentang persoalan kesetaraan gender melalui karya-karya bertema kehidupan keseharian perempuan. Kesetaraan dalam kegiatan intelektual untuk menambah ilmu pengetahuan, dan bukan dominasi pria saja pada saat itu. Perempuan perupa impresionis melukiskan kegiatan intelektual melalui visualisasi kaum wanita yang sedang membaca. Marie Bracquemond dalam karya Tea-Time (1880), melukiskan perempuan sedang membaca dengan ekspresi sungguh-sungguh dalam mencermati isi bacaannya. Latar belakang lukisan Marie adalah tetumbuhan, suasana di luar rumah. Berthe Morisot dalam karya Mother and Sister of the Artist (1870), memperlihatkan sosok perempuan berbaju hitam sedang membaca sebuah buku tebal dengan ekspresi serius. Berthe kembali mengggambarkan aktifitas membaca dalam karya Little Girl Reading (1888). Mary Cassatt dalam karya berjudul Woman Reading Le Figaro (1878), melukiskan ibunya sedang membaca koran. Divisualisasikan ekspresi wajah sangat serius mencermati tulisan dalam koran tersebut.

Lukisan perempuan perupa yang mengangkat aktifitas intelektual membaca buku atau koran tersebut, seakan ingin mengatakan pada masyarakat di zaman itu bahwa kaum perempuan berusaha tetap memiliki akses untuk menambah pengetahuan. Mereka menambah ilmu, meskipun aktifitas mereka hanya seputar kegiatan di rumah. Di sisi lain, perempuan perupa pada saat itu tampaknya mencoba mengurangi gambaran bahwa perempuan hanya pantas diekspos unsur keindahan tubuh mereka saja dan penggambaran perempuan yang terlibat dalam dunia malam maupun prostitusi yang sering dilukiskan oleh pria perupa. Èdouard Manet dalam karya Bar at the Folies-Bergére (1882) menjadikan perempuan pelayan bar sebagai objek utama lukisannya. Edgar Degas pun menjadikan kehidupan perempuan dalam dunia porstitusi sebagai objek lukisannya. Lukisan Edgar Degas lainnya menggambarkan seorang artis bernama Ellen Andrée dengan ekspresi sendu di sebelah pria seorang perupa bernama Marcellin Desboutin dengan penampilan kusut setelah meneguk minuman keras dalam karya berjudul In the Café (Absinthe) (1875-76).

Perempuan perupa impresionis yang tidak memiliki akses untuk menikmati kehidupan di kafe karena berkonotasi negatif bagi perempuan yang pergi mengunjungi tempat hiburan tersebut, justru mencoba berbicara tentang aktifitas perempuan yang tidak sebatas sebagai objek dalam lukisan kaum pria. Kegiatan intelektual maupun kegiatan lain yang mengggambarkan kemandirian perempuan coba dilukiskan oleh perempuan perupa.

Mary Cassatt melukiskan perempuan yang mengendarai kereta kudanya sendiri sementara kusir duduk pada bagian belakang dalam karya berjudul $A$ Women and a Girl Driving (1881). Situasi yang dilukiskan oleh Mary Cassatt bukanlah situasi yang umum di zaman itu. Para perupa perempuan ingin mengungkapkan 
tentang kelebihan seorang perempuan, seperti perempuan yang dapat melakukan berbagai aktifitas yang dikerjakan pria. Lukisan tersebut dibuat dengan komposisi yang menarik dengan 'memotong' gambar kuda yang bertujuan untuk lebih memfokuskan kepada perempuan yang mengendalikannya. Pemilihan warna merah muda pada baju anak kecil membangun kesan feminin, sekaligus aksen dari warna dominan hijau dan coklat.

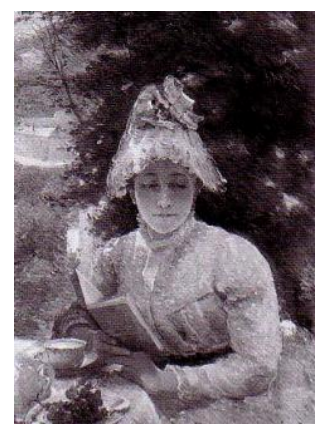

Gambar 9 Marie Bracquemond, Tea- Time (1880). Sumber: Chadwick, W., Women, Art, and Society, Fourth Edition, Thames and Hudson Ltd, London, 2007, h. 237.

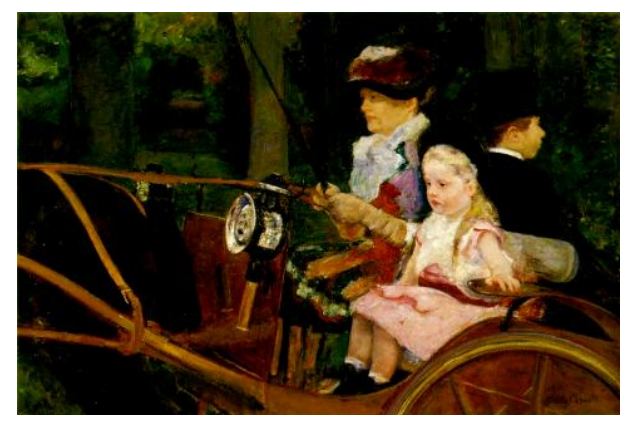

Gambar 10 Mary Cassatt, A Women and a Girl Driving (1881). Sumber: Brodskaïa, N., Cassatt, Grange Book, London, 2006, h. 55.

Mary Cassatt merupakan perempuan perupa abad ke-19 yang dianggap telah berpikiran modern. Anggapan tersebut muncul dari upayanya bersikap mandiri dan bagaimana ia dapat eksis di masyarakat melalui karyanya. Pemikiran tentang perempuan modern terungkap dalam karya mural untuk Woman's Building, World's Colombian Exposition, Chicago, 1893. Karyanya berjudul Modern Woman (1892-93), menggambarkan perempuan-perempuan muda yang mengejar anak kecil yang terbang, dianggap replika dari karya Cupid in Flight Fresco dari Pompeii yang diletakkan pada panel pertama. Karya ini melambangkan cinta atau kasih sayang. Pada panel tengah sebagai panel utama, digambarkan perempuan-perempuan muda yang memetik buah. Panel kedua ini merupakan simbol bagi perempuan yang mencari ilmu pengetahuan. Sedangkan dalam panel ketiga terlihat tiga orang perempuan terlihat sedang memainkan musik, menari dan menyanyi.

Pemaparan di atas memberikan gambaran bahwa perempuan perupa impresionis dapat mengungkapkan pemikiran mereka tentang perempuan dalam kehidupan keseharian, yang ternyata jauh berbeda dari gambaran pria perupa yang selalu berupaya menyembunyikan prestasi kaum perempuan. Perempuan perupa 
mengungkapkan aspirasi perempuan terhadap keinginan mencari ilmu, sikap mandiri, maupun bagaimana mereka mengungkapkan perasaan kasih sayang terhadap anak dalam karya seni. Sedikitnya akses ke ruang publik rupanya dapat dimanfaatkan oleh perempuan perupa saat itu untuk mengungkapkan kehidupan keseharian perempuan dengan cara pandang perempuan yang jelas berbeda dari cara pandang pria dalam memandang kehidupan keseharian perempuan.

Cara pandang perempuan perupa tersebut berdampak pada visualisasi karya mereka. Perempuan dapat menampilkan sudut penggambaran yang lebih menyentuh dalam menggambarkan hubungan ibu dan anak. Perempuan juga dapat memperlihatkan bagaimana pria terobsesi terhadap kaum perempuan, dalam karya Mary Cassatt berjudul Woman in Black at the Opera (1880). Karya tersebut menggambarkan perempuan yang sedang menikmati pertunjukan opera menggunakan teropong, tetapi di sudut lain terlihat seorang pria justru mengarahkan teleskopnya pada sosok perempuan itu, bukan pada pertunjukan yang ditampilkan. Situasi yang mungkin sering terjadi, tetapi tentu tidak menjadi perhatian pria karena mereka hanya akan memperhatikan keindahan fisik perempuan, bukan bercerita tentang pengalaman hidup perempuan.

Dengan demikian terlihat perbedaan antara pria perupa dan perempuan perupa dalam berekspresi tentang kehidupan keseharian perempuan. Perempuan memanfaatkan medium lukis untuk mengungkapkan pemikiran, perasaan mereka secara jujur. Pria cenderung menjadikan perempuan sebatas objek kesenangan estetis.

Para perempuan perupa impresionis telah berusaha mengungkapkan kehidupan perempuan, tetapi para feminist masih menganggap kehidupan yang diungkapkan baru sebatas kehidupan kelas atas. Perempuan pekerja di pabrikpabrik dan kehidupan mereka yang sulit pada periode abad ke- 19, masih belum terungkap dalam karya seni rupa. Perempuan perupa improsionis masih sibuk memantapkan posisi mereka dalam lingkungan patriarki. Meskipun demikian, keberanian mengungkapkan kehidupan perempuan dengan cara pandang perempuan sudah merupakan terobosan pada saat itu.

\section{$5 \quad$ Penutup}

Perempuan perupa impresionis memiliki kualitas estetis yang baik dari segi penguasaan teknik melukis maupun teknik mencetak karya grafis mereka. Kemampuan estetis mereka tampak pula dalam pengambilan sudut pandang dalam memvisualisasikan teknik melukis, serta goresan-goresan warna dalam lukisannya. 
Tema-tema yang dipilih oleh perempuan perupa serupa dengan tema yang dipilih oleh pria perupa dalam periode tersebut, yaitu berkaitan dengan kehidupan keseharian. Tidak adanya akses untuk menikmati kehidupan malam di kafe-kafe, perempuan perupa lebih banyak memilih tema kehidupan domestiknya. Tema yang dipilih seperti kegiatan berdandan, pengasuhan anak, menjahit, maupun minum teh.

Walaupun tema yang dipilih tidak jauh berbeda dengan pria perupa, tetapi kenyataannya terlihat jelas cara pandang pria dalam melukiskan kehidupan perempuan dengan cara pandang perempuan dalam melukiskan kehidupannya sendiri. Terdapat kecenderungan pria perupa lebih tertarik pada unsur sensualitas dari diri seorang perempuan, sedangkan perempuan perupa lebih senang mengangkat persoalan keibuan (motherhood) maupun kesetaraan gender dalam kegiatan intelektual sebagai objek karya seninya.

\section{Referensi}

[1] Broude, N., 2005, Mary Cassatt Modern Woman or the Cult of True Womanhood? dalam Broude, N. dan Garrard, M., Reclaiming Female Agency: Feminist Art History after Post Modernism, University of California Press, London.

[2] Cunningham, A., 2002, Impressionist, Parragon Book, United Kingdom.

[3] Winarno, I., 2007, Mencari Perempuan Perupa Dunia, Petik, Bandung.

[4] Chadwick, W., 2007, Women, Art, and Society, Fourth Edition, Thames and Hudson Ltd, London.

[5] Fichner, L., 1995, Understanding Art, Forth ed., Prentice Hall, New Jersey.

\section{Website}

http://www.nmwa.org/collection diakses 30 Maret 2007 